\title{
Cieszyn-Czeski Cieszyn - wybrane aspekty funkcjonowania miasta podzielonego na granicy polsko-czeskiej w kontekście transgranicznej mobilności mieszkańców
}

Głównym celem artykułu jest analiza otwartości transgranicznej firm usługowych działających w mieście podzielonym Cieszyn-Czeski Cieszyn i powiązań między mieszkańcami obu miast. Elementy podlegające badaniu stanowią jedynie fragment całokształtu relacji transgranicznych, na które składa się cały kompleks relacji w sferze politycznej czy też gospodarczej. Jednakże kwestia otwartości firm na klientów z drugiej strony granicy oraz motywacje i częstość przekraczania granicy przez mieszkańców, a także percepcja sąsiadów stanowią istotny aspekt praktyk transgranicznych. Ich analiza pozwala na identyfikację charakteru powiązań transgranicznych o wymiarze lokalnym z punktu widzenia codziennego życia mieszkańców miasta podzielonego granicą państwową. Analiza przestrzeni instytucjonalnej pozwala uchwycić kształtowanie się procesów oddolnych, które są w znacznej mierze niezależne od inicjatyw podejmowanych przez władze lokalne.

Słowa kluczowe: miasta podzielone, miasta graniczne, granica polsko-czeska, relacje transgraniczne, transgraniczna turystyka zakupowa.

\section{Wprowadzenie}

Miasta zlokalizowane na granicy państwowej mogą być uznane za swoiste laboratoria integracji. Z uwagi na odczuwalne w codziennym życiu mieszkańców istnienie granicy i bliskość kraju sąsiedniego, różnego rodzaju praktyki transgraniczne wydają się mieć większe znaczenie niż na pozostałych obszarach pogranicza. Tutaj także silnie odczuwalny jest praktyczny wymiar podejmowanych wspólnie działań integracyjnych lub ich brak. Jest to istotne zarówno w wymiarze materialnym, obejmującym m.in. kwestie transportu transgranicznego, planowania przestrzennego, działalności służb ratowniczych czy policyjnych, jak i w wymiarze niematerialnym - kształtowaniu się tożsamości lokalnej, stereotypów narodowych, promocji miast.

Artykuł podejmuje zagadnienie otwartości transgranicznej firm usługowych działających w miastach podzielonych. Jest to jeden z elementów kształtujących obraz miasta, które jest przedzielone granicą państwową. Na całokształt relacji transgranicznych składa się zespół uwarunkowań w sferze politycznej, histo- 
rycznej, kulturowej, gospodarczej i wynikających z tego różnorakich praktyk transgranicznych. Kwestia otwartości firm na klientów z drugiej strony granicy stanowi jeden $\mathrm{z}$ wymiarów integracji miast podzielonych, ale jest także wyrazem uwarunkowań i relacji obserwowanych w mieście. Analiza przestrzeni instytucjonalnej miasta podzielonego pozwala uchwycić kształtowanie się procesów oddolnych, które są w znacznej mierze niezależne od inicjatyw podejmowanych przez władze lokalne. Dodatkowym problemem podjętym w artykule jest kwestia mobilności transgranicznej mieszkańców w wymiarze lokalnym. Powiązanie dwóch części miasta podzielonego granicą państwową poprzez codzienne praktyki mieszkańców, związane z jej przekraczaniem i realizacją różnego typu potrzeb w kraju sąsiednim, stanowi bardzo ważny element relacji transgranicznych.

Badanie miało pozwolić na odpowiedź, czy w mieście podzielonym Cieszyn-Czeski Cieszyn przestrzeń instytucjonalna jest symetryczna czy też asymetryczna. Celem było także określenie charakteru powiązań mieszkańców polskiej części miasta ze stroną czeską. Skupiono się przy tym na relacjach związanych $\mathrm{z}$ handlem transgranicznym.

Inwentaryzację podmiotów gospodarczych przeprowadzono na obszarze centrów badanych miast we wrześniu $2011 \mathrm{r}$. Badaniem objęto 432 firmy sektora usług (130 w Czeskim Cieszynie i 302 w Cieszynie), które były oznaczone i bezpośrednio dostępne z ulicy. Na podstawie inwentaryzacji uzyskano dane o czterech cechach otwartości na klientów z drugiej strony granicy państwowej (kategorie otwartości transgranicznej):

- szyld w języku kraju sąsiedniego,

- materiały marketingowe w języku kraju sąsiedniego (np. ulotki, cennik, menu, wizytówki),

- możliwość płatności w walucie kraju sąsiedniego,

- podstawowa znajomość języka kraju sąsiedniego wśród pracowników.

Wymienione powyżej cztery kategorie otwartości transgranicznej pomogły określić nastawienie placówek usługowych w miastach podzielonych do klientów z drugiej strony granicy. Ich analiza pozwoliła na ocenę, czy firmy sektora usług w swojej działalności biorą pod uwagę zaspokajanie nie tylko popytu lokalnego, ale także popytu na produkty i usługi wśród mieszkańców miasta sąsiedniego. Dzięki informacji o lokalizacji poszczególnych placówek uzyskano ponadto obraz rozmieszczenia przestrzennego firm pod względem badanych kategorii. Pozwoliło to na uwzględnienie, oprócz analizy statystycznej, także wymiaru przestrzennego zjawiska otwartości transgranicznej firm w miastach podzielonych $^{1}$.

${ }^{1}$ Analiza nie objęła supermarketów oraz targowisk, gdyż znajdowały się one poza centrum miejskim, które stanowiło obszar badania. 
Przeprowadzone badanie ankietowe wśród mieszkańców Cieszyna (próba celowa 150 osób) miało na celu identyfikację motywacji oraz określenie intensywności odwiedzin w Czeskim Cieszynie. Badanie właściwe, zrealizowane w czerwcu 2011 r., było poprzedzone pilotażem.

\section{Teoretyczne aspekty funkcjonowania miast podzielonych}

Analizując funkcjonowanie firm w miastach podzielonych, kilka kwestii wydaje się mieć szczególne znaczenie, a mianowicie kwestia granicy państwowej i jej roli, specyfika miast podzielonych oraz transgraniczna mobilność związana z zakupami (turystyka zakupowa). Granica jest konstruktem politycznym, ale także społecznym (Newman 2006, 2010, Paasi 2011). Może ona stanowić nie tylko barierę polityczną, ale także przestrzenną, komunikacyjną, ekonomiczną, kulturową, historyczną, czy, co równie istotne, mentalną (van Houtum 1999, Rippl i in. 2010, Brunet-Jailly 2011). Granica państwowa zawsze stanowi pewną barierę, nawet na obszarach silnie zintegrowanych, jak np. w Unii Europejskiej (Bygvrå, Westlund 2004, O’Dowd 2010). W miarę postępów globalizacji i integracji rola granicy jako bariery (np. kontrolnej) zmniejsza się, w sytuacji sprzyjających warunków, jej negatywne efekty są odczuwalne tylko w nieznaczny sposób, ale nie znika zupełnie (Ackleson 2005). Charakterystyczne jest, że granica państwowa może jednocześnie stanowić barierę, ale także pewnego rodzaju szansę, jest źródłem korzyści, ale zarazem problemów (Agnew 2008, van der Velde, Sperings 2010, Sohn, Lara-Valencia 2013). Co istotne, równocześnie mogą być odczuwane jej negatywne, jak i pozytywne efekty. Powszechne jest kojarzenie pojęcia granicy z barierą, jednakże lokalizacja przygraniczna może stanowić potencjalnie czynnik rozwoju lokalnego (Reitel 2006, Gerber, Lara, de la Parra 2010, Sohn 2013). Pozytywne efekty lokalizacji przygranicznej w zależności od roli granicy oraz uwarunkowań lokalnych mogą być odczuwalne w większym lub mniejszym stopniu. Wydaje się jednak, że procesy integracji w Europie mogą przyczynić się do zmiany postrzegania przygranicznej lokalizacji z problematycznej na stanowiącą pewną zaletę. Miasta podzielone mają szansę stać się miejscami o intensywnej współpracy transgranicznej, mogą stanowić pewnego rodzaju łącznik między sąsiadującymi krajami (szczególnie między ich regionami przygranicznymi) i sprzyjać wspólnemu rozwiązywaniu problemów, ale także osiąganiu wspólnych celów rozwojowych (Dołzbłasz, Raczyk 2012).

Należy zauważyć, że do określania miast zlokalizowanych na/przy granicy państwowej używa się wielu terminów, dlatego panuje $\mathrm{w}$ tej kwestii chaos terminologiczny. Brak jest jednej, ogólnie przyjętej definicji miast bezpośrednio sąsiadujących przez granicę państwową, a także jednolitej klasyfikacji tego typu 
jednostek osadniczych. W używanych nazwach zwraca się uwagę na genezę tego typu układów osadniczych, współczesne funkcjonowanie, wielkość, uwarunkowania kulturowe czy też przyrodnicze. Funkcjonują takie określenia, jak m.in. miasta podzielone, miasta rozerwane, miasta bliźniacze, miasta siostrzane, pary miejskie, miasta graniczne, miasta transgraniczne, miasta dwupaństwowe, przygraniczne obszary metropolitarne. $\mathrm{Z}$ najczęściej stosowanych, $\mathrm{z}$ reguły w węższym rozumieniu, używany jest termin ,miasto podzielone”, odnośnie do miast, które w przeszłości stanowiły jedną jednostkę osadniczą i zostały podzielone granicą, tworząc w efekcie osobne miasta (jednakże termin ten jest aktualnie często stosowany w kontekście konfliktów, a także podziałów m.in. językowych, etnicznych wewnątrz jednego miasta). Szersze znaczenie ma pojęcie „miasta bliźniacze”, które zakłada bezpośrednią bliskość jednostek miejskich, ale nie musi ona być rezultatem podziału jednej jednostki, lecz wynikać $\mathrm{np}$. $\mathrm{z}$ rozwoju miast w pobliżu granicy po obu jej stronach i postępującego zbliżania, aż do przestrzennego sąsiedztwa przez granicę. Termin ten jest także używany do określenia pary miast, które ze sobą współpracują i niekoniecznie sąsiadują. Najczęściej stosuje się termin „miasto graniczne”. Z reguły dotyczy miast zlokalizowanych tuż przy granicy, w bezpośredniej bliskości innej jednostki miejskiej po jej drugiej stronie. Służy także do określania miast zlokalizowanych $\mathrm{na} / \mathrm{w}$ pobliżu granicy, niekoniecznie sąsiadujących z miastem zagranicznym, ale w którym jest silnie odczuwany wpływ granicy na jego funkcjonowanie (Arreola 1996, Jańczak 2009, 2013, Lundén 2004, Kulczyńska 2010, Sohn, Lara-Valencia 2013). Jańczak zauważa, że właściwą nazwą jest „graniczne miasta bliźniacze”, podkreślające bezpośrednie sąsiedztwo miast przez granicę państwową bez względu na genezę takiej pary (Jańczak 2013).

Należy zauważyć, że geneza miast podzielonych może być różna (Sohn, Lara-Valencia 2013):

- długoletni rozwój miasta jako całości, następnie podział granicą państwową i powstanie „nowych” dwóch miast (np. Zgorzelec-Görlitz na granicy polsko-niemieckiej po 1945 r.);

- ustanowienie granicy, która odcina od miasta jego przedmieście, co powoduje na ich bazie rozwój nowego miasta tuż za nową granicą państwową (Frankfurt nad Odrą-Stubice po 1945 r., Laredo w Stanach Zjednoczonych Ameryki po 1848 r.);

- powstanie miasta od podstaw, np. w celu wzmocnienia obronnej funkcji granicy (m.in. Eagle Pass i Piedras Negras na granicy USA z Meksykiem), czy też motywowane kwestiami ekonomicznymi i administracyjnymi (np. Haparanda na granicy szwedzko-fińskiej).

Podobnie jak odmienna może być geneza miast podzielonych, różnie mogą przebiegać procesy transgranicznej integracji struktur miejskich (Reitel 2013). 
Peryferyjne położenie miast granicznych z reguły ma negatywny wpływ na ich rozwój. Dotyczy to zresztą całych regionów przygranicznych, powodując ich niedorozwój (Sohn, Lara-Valencia 2013, Vaishar i in. 2013). Jednakże w sytuacji redukcji barier formalnych związanych z granicą państwową oraz występowania korzystnych uwarunkowań społeczno-gospodarczych, graniczne położenie może stanowić impuls rozwoju dla miast podzielonych. Wydaje się przy tym, że intensyfikacja współpracy transgranicznej (zarówno formalnej, jak i nieformalnej) ma zdecydowanie pozytywny wpływ na przeciwdziałanie peryferyjności (Knippschild 2011) i korzystnie oddziałuje na funkcjonowanie regionów przygranicznych, w tym także miast granicznych. Należy przy tym pamiętać, że dynamiczny rozwój współpracy transgranicznej z reguły nie przekłada się w sposób bezpośredni na rozwój gospodarczy, który generowany jest przez cały konglomerat czynników wewnętrznych i zewnętrznych (Krätke, Borst 2007). $\mathrm{Z}$ pewnością jednak sprzyja integracji dwóch części miasta podzielonego (w wymiarze przestrzennym, społecznym, gospodarczym). Jednak aktywność gospodarcza często jest przyczyną dynamicznego rozwoju miast granicznych. W tym kontekście należy podkreślić, że mówiąc o postępach integracji na pograniczach, należy pamiętać, że intensywność wymiany między obszarami po dwu stronach granicy wcale nie musi być związana z postępującą konwergencją ich struktur, ale wręcz przeciwnie, może być silnie związana z dużymi zróżnicowaniami społeczno-ekonomicznymi (Arreola 1996, Topaloglou i in. 2005).

Transgraniczna turystyka zakupowa stanowi istotny wymiar relacji transgranicznych o bardzo praktycznym charakterze. Ich kierunek, natężenie, koszyk dóbr i usług itp. zależy od aktualnych uwarunkowań istniejących w krajach sąsiednich. Istotną rolę odgrywa oczywiście rola granicy jako bariery (im jest ona trudniej przekraczalna, tym bardziej tego typu mobilność jest ograniczona), warunki polityczne (ważne generalnie dla rozwoju współpracy transgranicznej) oraz elementy ściśle związane $\mathrm{z}$ funkcjonowaniem usług w wymiarze transgranicznym, takie jak m.in. poziom cen po obu stronach granicy, siła nabywcza mieszkańców, możliwości transportowe. Należy podkreślić, że turystyka zakupowa może stanowić podstawę gospodarczą funkcjonowania obszarów/miast przygranicznych, generując większość przychodów firm i przez to dochodów mieszkańców. Transgraniczna mobilność związana z korzystaniem z usług po drugiej stronie granicy państwowej może stanowić jeden z elementów generujących zachowania kooperacyjne zarówno ze strony władz miejskich ułatwiających transgraniczne praktyki (np. poprzez politykę transportową), jak i firm oraz mieszkańców (współpraca firm, wzajemne poznanie się mieszkańców i podejmowanie innych wspólnych działań). Mogą one jednak powodować negatywne nastawienie, np. wśród przedsiębiorców, w sytuacji gdy mieszkańcy robią zakupy i korzystają z usług po drugiej stronie granicy, obniżając zatem dochody 
firm rodzimych. W tym kontekście najbardziej pożądana jest komplementarna struktura podmiotów gospodarczych, niegenerująca nasilenia postaw konkurencyjnych.

W zjawisku transgranicznej mobilności konsumentów obserwuje się dwie przeciwstawne tendencje, pierwsza zwiększa mobilność, a druga ją zmniejsza. W ramach pierwszej grupy czynników można wyróżnić czynniki przyciągające klientów do kraju sąsiedniego i czynniki wypychające konsumentów z ich kraju rodzimego. W ramach czynników zmniejszających transgraniczną mobilność wyróżniamy czynniki zniechęcające mieszkańców do opuszczania swojego kraju oraz czynniki zniechęcające do wizyt w kraju sąsiednim (Spierings, van der Velde 2008). W kształtowaniu mobilności konsumentów istotną rolę odgrywają różnorodne elementy, takie jak m.in. ceny, jakość, różnorodność dóbr i usług, poczucie ciekawość i obcości, znajomość uregulowań, jakość przestrzeni publicznej. Bardzo ważną kwestią są racjonalne i emocjonalne różnice, mające wpływ na poziom poczucia obcości. Jak stwierdzili M. van der Velde, B. Spierings (2010), zarówno zbyt duże różnice, jak i ich brak powodują redukcję transgranicznej mobilności. Z punktu widzenia jej rozwoju najkorzystniejsza jest sytuacja „oswojonej obcości”, gdy po drugiej stronie granicy jest inaczej niż u nas i to nas przyciąga, ale te różnice nie są za duże i nas nie odstraszają (Spierings, van der Velde 2008). Należy podkreślić, że transgraniczne zakupy z uwagi na różne warunki po dwu stronach granicy z reguły mają charakter asymetryczny, jednak nie jest on statyczny i może ulegać zmianom (Leimgruber 2005).

\section{Uwarunkowania lokalne w mieście podzielonym Cieszyn-Czeski Cieszyn}

Analizując uwarunkowania funkcjonowania miast podzielonych, należy wziąć pod uwagę spektrum czynników, z których część wynika z cech sąsiadujących państw i ich regionów granicznych (uwarunkowania krajowe i regionalne), a część ze specyfiki samych miast (uwarunkowania lokalne). Z pewnością bardzo ważnym elementem jest rola granicy państwowej, im większa jej formalizacja, tym, generalnie, większe ograniczenia dla rozwoju miast podzielonych. W tym kontekście, w warunkach przynależności zarówno Polski, jak i Czech do układu z Schengen, potencjalne warunki do integracji miast Cieszyn i Czeski Cieszyn są zdecydowanie sprzyjające. Należy przy tym podkreślić przyjazne relacje na poziomie krajowym między Polską i Czechami oraz na szczeblu regionalnym między województwem śląskim (Cieszyn) a Krajem Morawsko-Śląskim (Czeski Cieszyn). Ponadto obserwuje się relatywnie intensywną formalną współpracę transgraniczną realizowaną w ramach programów EU przez jednostki administracji szczebla lokalnego i inne instytucje (stowarzyszenia, 
fundacje, instytucje kulturalne, szkoły) z tych miast. Oba miasta wyróżniają się realizacją znacznej liczby projektów, które stanowią ważne ogniwa współpracy transgranicznej (Dołzbłasz 2013).

Wśród najważniejszych czynników kształtujących relacje transgraniczne należy wymienić zróżnicowanie poziomu rozwoju społeczno-gospodarczego po obu stronach granicy. W przypadku występowania dużych różnic współpraca jest utrudniona, natomiast zbliżony poziom ułatwia relacje transgraniczne. $\mathrm{Na}$ pograniczu polsko-czeskim obserwuje się podobny poziom rozwoju i różnice są relatywnie niewielkie (First Espon Synthesis Report 2013). Należy jednak zauważyć, że występowanie dużych różnic $\mathrm{w}$ tym zakresie oraz związanego $\mathrm{z}$ tym m.in. zróżnicowania poziomu dochodów i cen po dwóch stronach granicy może mieć wpływ na intensyfikację powiązań i mobilności mieszkańców, np. dojazdów do pracy, dokonywania zakupów produktów i usług po drugiej stronie granicy.

Podobieństwo problemów, wyzwań i celów rozwoju społeczno-gospodarczego ma istotne znaczenie dla relacji transgranicznych. W tym zakresie również można mówić o relatywnym podobieństwie obu części pogranicza polsko-czeskiego, w tym także w Cieszynie i Czeskim Cieszynie, np. podobieństwo struktur gospodarczych, wspólne obszary górskie, rozwój turystyki, proces integracji z UE, występowanie obszarów problemowych, poszukiwanie czynników rozwoju (Pokluda 2005, Vaishar i in. 2013). Biorąc pod uwagę czynniki historyczne i kulturowe (m.in. negatywne stereotypy narodowościowe, percepcja kraju sąsiedniego, podobieństwo kulturowe, w tym językowe i religijne, bagaż historyczny), można stwierdzić, że w porównaniu z innymi fragmentami polskich granic na omawianym pograniczu bariery są względnie słabe. Mniejszość polska po czeskiej stronie jest liczniejsza niż czeska po polskiej, według spisu ludności z 2001 r. 15,9\% mieszkańców Czeskiego Cieszyna zadeklarowało narodowość polską (Siwek 2008). Na podstawie analizy nazwisk mieszkańców Czeskiego Cieszyna zaobserwowano natomiast, że ok. $40 \%$ ma polskie pochodzenie (Siwek 2008). Jednym z czynników ograniczających współpracę transgraniczną jest przeszłość tych ziem, m.in. walki o Zaolzie (Buttin 2006) mogą jeszcze powodować występowanie postawy niechęci wobec mieszkańców po drugiej stronie granicy. Należy jednak podkreślić, że wraz z upływem lat są one coraz słabsze.

Uwarunkowania historyczne mają duże znaczenie dla współdziałania badanych miast. Cieszyn wielokrotnie zmieniał swą przynależność państwową od momentu powstania w X w., a cały Śląsk Cieszyński, którego jest stolicą, stanowił do 1920 r. odrębną całość pod względem zarówno kulturowym (będąc typowym środkowoeuropejskim tyglem narodowościowym i kulturowym), jak i administracyjnym (w ramach polskiej, potem czeskiej i austriackiej organizacji państwowej). Problem przynależności państwowej tego obszaru pojawił się 
w 1918 r., kiedy Polska i Czechosłowacja odzyskały niepodległość i konieczne stało się wytyczenie między nimi granicy. Oba państwa rościły sobie prawa do tego obszaru. Na mocy arbitrażu międzynarodowego zespół miejski Cieszyn został podzielony w 1920 r. granicą państwową, biegnącą wzdłuż rzeki Olzy. Główna część miasta, leżąca na prawym brzegu Olzy, weszła w skład Polski, natomiast część lewobrzeżna przypadła Czechosłowacji (Zenderowski 2002a, b).

Istotny element $\mathrm{w}$ kształtowaniu relacji transgranicznych mogą stanowić również uwarunkowania przyrodnicze (Więckowski 2013). W badanym mieście granica oparta jest na rzece Olzie (co stanowi w pewnym stopniu wyjątkową sytuację na granicy polsko-czeskiej, która w większości wytyczona została na obszarze górskim). Miało to wpływ na rozwój przestrzenny obu miast po ich podzieleniu granicą państwową. Rozdzielenie rzeką ogranicza możliwość integracji obu części miasta $\mathrm{w}$ wymiarze przestrzennym, gdyż powiązania sprowadzają się do przepraw mostowych. Z punktu widzenia potencjalnej możliwości integracji tych fragmentów korzystne jest funkcjonowanie mostów w punktach centralnych miast (łączących główne obszary usługowe, historyczne itp.). Są to połączenia istotne z punktu widzenia ruchu kołowego i pieszego ${ }^{2}$. Na skutek podziału historycznego centrum z rynkiem i zamkiem znalazło się po polskiej stronie, aczkolwiek z uwagi na istniejący układ urbanistyczny jest ono bardzo blisko granicy, gdyż rzeka przepływa przez centrum miasta. Obie części miasta charakteryzują się względną symetrycznością pod względem wielkości, Cieszyn ma 28,5 km² powierzchni i ok. 36 tys. ludności, natomiast Czeski Cieszyn $34 \mathrm{~km}^{2}$ powierzchni i ok. 25 tys. mieszkańców. Biorąc pod uwagę te uwarunkowania, można stwierdzić istnienie względnej symetrii struktur funkcjonalno-przestrzennych w zespole miejskim Cieszyn-Czeski Cieszyn.

W kontekście analizy otwartości transgranicznej firm zlokalizowanych w miastach podzielonych, oprócz omówionych uwarunkowań, istotne są także ceny produktów i usług oraz struktura placówek usługowych. Bezpośrednia bliskość centrów obu części miast i istnienie między nimi połączenia dzięki przeprawie mostowej ma pozytywny wpływ na relatywnie dobrą dostępność do placówek usługowych (koncentrujących się w centrum) dla mieszkańców z drugiej strony rzeki granicznej. Bliskość przestrzenna oraz niewielka dysproporcja infrastrukturalna to kolejne elementy kształtujące symetrię miasta podzielonego. Należy zauważyć, że znaczna część mieszkańców Cieszyna i Czeskiego Cieszyna (58\%) w dalszym ciągu postrzega miasto jako całość (Kulczyńska, Matykowski 2011).

Bardzo ważny z punktu widzenia transgranicznej otwartości placówek usługowych jest poziom cen w sąsiadujących krajach. Ceny żywności w 2012 r.

\footnotetext{
${ }^{2} \mathrm{~W}$ Cieszynie istnieje również ważne połączenia tranzytowe (na drodze S1).
} 
w Polsce kształtowały się na poziomie 60\% średniej UE, natomiast w Czechach - na poziomie $82 \%$ (Kurkowiak 2013). Napoje niealkoholowe w Polsce kosztowały średnio $79 \%$ średniej dla UE, a w Czechach - 98\%. Ceny tych artykułów w Polsce były najniższe w całej UE (podobnie jak najniższe były ceny mięsa, ryb, mleka i jego przetworów, warzyw, owoców, olejów i innej żywności, a ceny chleba i produktów zbożowych jedne z najniższych). Jeśli chodzi o ceny alkoholi, sytuacja kształtowała się nieco odmiennie. Poziom cen w Polsce i w Czechach był wyrównany i wynosił odpowiednio 93\% i 96\% średniej unijnej. Ceny tytoniu również były niższe w Polsce niż w Czechach (odpowiednio 58\% i 69\% średniej UE), lecz różnica nie była tak duża jak w przypadku cen żywności i napojów bezalkoholowych.

Od lat 90. XX w. na skutek większego otwarcia granicy polsko-czeskiej rola handlu detalicznego w strukturze przestrzenno-funkcjonalnej zespołu miejskiego Cieszyn-Czeski Cieszyn zaczęła wzrastać, generując specyficzne formy handlu nastawione na obsługę konsumentów z drugiej strony granicy i tworząc nowe formy sklepów wielkopowierzchniowych (Kulczyńska, Matykowski 2008). Zróżnicowanie cenowe produktów sprzyjało wzajemnej turystyce zakupowej (na początku lat 90. liczba ta wynosiła 50-70 tys. osób w dni targowe) (Konecka, Weltrowska 1997, za: Kulczyńska, Matykowski 2008). Na skutek zbliżenia się cen, natężenie ruchu zdecydowanie zmalało i w 2007 r. kształtowało się na poziomie 7-10 tys. osób. Niemniej nadal obserwuje się przemieszczenia przez granicę w celach zakupowych. Wśród konsumentów można wyróżnić dwie zasadnicze grupy: mieszkańców obu miast, którzy po drugiej stronie granicy kupują towary w podobnej cenie jak w swojej ojczyźnie, ale uznanych przez nich za lepsze, oraz konsumentów spoza Cieszyna, którzy przybywają na ogół na zakupy weekendowe, poszukując towarów o najniższych cenach (Kulczyńska, Matykowski 2008). Obecnie Polacy w Czechach kupują głównie alkohol, wyroby tytoniowe, słodycze i zdrową żywność.

\section{Mobilność mieszkańców i otwartość placówek usługowych w wymiarze transgranicznym w Cieszynie i Czeskim Cieszynie}

Na podstawie wyników badania ankietowego można stwierdzić, że większość mieszkańców Cieszyna często odwiedzała miasto po drugiej stronie rzeki granicznej ${ }^{3}$. Biorąc pod uwagę cele i częstotliwość przekraczania granicy przez mieszkańców Cieszyna, można stwierdzić, że przynajmniej raz w miesiącu przechodzili oni na drugą stronę mostu, przede wszystkim w celu zrobienia

\footnotetext{
${ }^{3}$ Niestety brak danych o mobilności transgranicznej mieszkańców Czeskiego Cieszyna uniemożliwia porównanie zachowań mieszkańców obu części miasta podzielonego.
} 
zakupów (ok. 75\% badanych), odwiedzenia bliskich (ok. 35\%) lub spędzenia wolnego czasu w Czeskim Cieszynie (80\%). Wśród mieszkańców, którzy robili zakupy w Czeskim Cieszynie, 2\% robiło zakupy codziennie, 12\% kilka razy w tygodniu, a niecałe $30 \%$ kilka razy w miesiącu, ponad $30 \%$ co najmniej raz w miesiącu. Należy podkreślić, że motywy zakupowe generowały najczęstszą mobilność transgraniczną mieszkańców Cieszyna (ok. 15\% mieszkańców codziennie lub kilka razy w tygodniu robiło zakupy po drugiej stronie). Niecałe $10 \%$ ankietowanych przekraczało granicę, aby dotrzeć do swojego miejsca pracy, a ok. $1 \%$ badanych przechodził na czeską stronę kilka razy w miesiącu w celach edukacyjnych. Prawie 50\% ankietowanych mieszkańców Cieszyna miało rodzinę, przyjaciół, znajomych po czeskiej stronie, a ok. 5\% współpracowników. Ma to z pewnością wpływ na relatywnie duże znaczenie odwiedzin rodziny oraz przyjaciół wśród motywów przekraczania granicy.

Biorąc pod uwagę wiedzę na temat organizowanych w mieście wspólnych polsko-czeskich wydarzeń kulturalnych, wystaw, czy też konkursów, widać wyraźnie, że mieszkańcy Cieszyna w większości orientują się w tego typu działaniach. Aż 95\% ankietowanych wiedziało, że są organizowane, a 97\% uważało je za potrzebne (przeciwnego zdania było tylko 3\% odpowiadających). Bardzo wysoki udział wśród ankietowanych zwolenników wspólnych polsko-czeskich wydarzeń kulturalnych i sportowych pozwala sądzić, że mieszkańcy obu części podzielonego miasta lubią spędzać czas w ramach tej formy aktywności. Oba miasta organizują razem wiele wspólnych polsko-czeskich imprez (m.in. festiwale filmowy i teatralny, koncerty muzyki poważnej, koncerty jazzowe, Święto Trzech Braci). Wpłynęły one nie tylko na pogłębianie relacji między mieszkańcami Cieszyna i Czeskiego Cieszyna, ale także przyciągnęły wielu turystów, stanowiąc ważny element promocji dla obu miast.

Wyniki badania wykazały, że Polacy mają przyjazny stosunek do Czechów. Aż $66 \%$ ankietowanych lubiło lub bardzo lubiło sąsiadów zza granicy. Dla $31 \%$ byli oni obojętni, a tylko 3\% stwierdziło, że nie lubi Czechów. Świadczy to o dobrych relacjach i pozytywnym nastawieniu do zagranicznego sąsiada. Można przypuszczać, że jest to w dużym stopniu efekt wielorakich działań władz lokalnych, mających na celu integrację mieszkańców obu miast.

Należy zaznaczyć, że wzajemne nastawienie mieszkańców Cieszyna i Czeskiego Cieszyna do sąsiadów z drugiej części miasta było generalnie przyjazne (przy tym mieszkańcy Czeskiego Cieszyna w większym odsetku wykazywali przyjazne postawy), podobnie pozytywne były wzajemne opinie o sobie. Stosunkowo niewielką rolę odgrywały tutaj uprzedzenia i stereotypy. O ile wśród mieszkańców Cieszyna dominuje średnia i słaba znajomość języka czeskiego, o tyle w przypadku mieszkańców Czeskiego Cieszyna - w dużej mierze za sprawą zamieszkującej go relatywnie licznej mniejszości polskiej - przeważa 
dobra znajomość języka polskiego. Trzeba przy tym zauważyć, że dużą rolę we wzajemnej komunikacji odgrywa lokalna gwara - swoista mieszanka gwary cieszyńskiej, słów polskich, czeskich i niemieckich (Zenderowski 2002a).

Badanie transgranicznej otwartości placówek usługowych w obu częściach miasta podzielonego Cieszyn-Czeski Cieszyn objęło ich obszary centralne. Inwentaryzację przeprowadzono wśród podmiotów gospodarczych z terenu ograniczonego po polskiej stronie ulicami: Zamkową, Michejdy, Kochanowskiego, Limanowskiego, Schodową i Łyska, a po czeskiej stronie - ulicami: Hlavní Třída, Nádražní, Střelniční, Nábřeží Míru, Štefánikova, Božkova. Obszar badań, centra obu miast, charakteryzuje się dużą koncentracją podmiotów gospodarczych oraz dobrą dostępnością dla klientów zza drugiej strony granicy, ze względu na bliskość mostu granicznego. Po polskiej stronie największa koncentracja placówek usługowych jest przy ulicach Głębokiej i Zamkowej oraz na Rynku i uliczkach od niego odchodzących. Po stronie czeskiej natomiast najwięcej podmiotów gospodarczych znajduje się przy ulicy Hlavní Tř́da. W mieście Czeski Cieszyn zasadniczym obszarem penetracji konsumentów polskich jest centrum bezpośrednio przylegające do granicy, ograniczone ulicami: Hlavní Tř́ída, Nádražní i Střelniční. Porównując strony polską i czeską, widać różnicę w liczbie oraz rozmieszczeniu instytucji usługowych. W Cieszynie jest ich więcej i są bardziej rozproszone, natomiast w Czeskim Cieszynie tworzą wyraźne skupienie przy ulicy Hlavní Třída. W badanych jednostkach rozkład przestrzenny firm był wynikiem historycznie uwarunkowanego procesu rozwoju przestrzennego miast i w głównej mierze wynikał z istniejącego układu urbanistycznego (rynek po stronie polskiej, główna ulica od przejścia granicznego do centrów miast sąsiednich).

W strukturze rodzajowej badanych firm wyraźnie widoczna była dominacja placówek handlu detalicznego (co jest powszechne w strukturze podmiotów gospodarczych w miastach). Po polskiej stronie $70 \%$ wszystkich badanych firm należało do sekcji G (handel), a po stronie czeskiej - prawie $75 \%$. Biorąc pod uwagę odsetek wybranych rodzajów placówek usługowych, widoczne są pewne prawidłowości (tab. 1). W Czeskim Cieszynie (szczególnie w pobliżu mostu łączącego oba miasta) charakterystyczny był znaczny udział sklepów spożywczych, co jest warunkowane zapotrzebowaniem miejscowym i popytem wśród klientów polskich ${ }^{4}$ na czeskie artykuły spożywcze - z uwagi na ich rodzaj, jakość, a w mniejszym stopniu niższą cenę. W Czeskim Cieszynie znaczący był także udział sklepów z alkoholem, który cieszy się bardzo dużą popularnością

${ }^{4}$ Udział sklepów spożywczych byłby większy, gdyby nie fakt, że znaczna część popytu lokalnego na artykuły spożywcze jest zaspokajana w supermarketach, które nie podlegały badaniu. 
wśród polskich klientów z Cieszyna i jego okolic. Podobnie po czeskiej stronie więcej było restauracji i kawiarni, co w większym stopniu wynika $\mathrm{z}$ uwarunkowań kulturowych i dużego popytu na tego rodzaju usługi wśród Czechów.

Tabela 1. Udział podmiotów gospodarczych $\mathrm{w}$ wybranych kategoriach w centrach miasta podzielonego Cieszyn-Czeski Cieszyn w 2011 r.

\begin{tabular}{|l|c|c|}
\hline \multirow{2}{*}{\multicolumn{1}{|c|}{ Rodzaj działalności }} & \multicolumn{2}{c|}{$\begin{array}{c}\text { Udział podmiotów } \\
\text { gospodarczych w \% }\end{array}$} \\
\cline { 2 - 3 } & Cieszyn & Czeski Cieszyn \\
\hline Sklep odzieżowy & $\mathbf{2 0}$ & 7 \\
\hline Restauracja, bar, kawiarnia & 8 & $\mathbf{1 5}$ \\
\hline Sklep spożywczy & 6 & $\mathbf{1 3}$ \\
\hline Salon fryzjerski, salon kosmetyczny & 6 & 2 \\
\hline Sklep meblowy & $\mathbf{4}$ & - \\
\hline Bank & 4 & 2 \\
\hline Sklep obuwniczy & 4 & 2 \\
\hline Apteka & 2 & 2 \\
\hline Jubiler & 2 & 2 \\
\hline Kantor wymiany walut & 2 & - \\
\hline Biuro podróży, informacja turystyczna & 2 & 2 \\
\hline Sklep z artykułami kosmetycznymi & 2 & 2 \\
\hline Sklep z artykułami papierniczymi & 2 & 2 \\
\hline Sklep z alkoholem & 1 & $\mathbf{1 2}$ \\
\hline Biuro nieruchomości & 1 & - \\
\hline Kasyno & - & 2 \\
\hline Inne & 37 & 36 \\
\hline
\end{tabular}

Źródło: opracowanie własne.

W Cieszynie wyraźnie więcej niż po czeskiej stronie było natomiast sklepów meblowych. Meble stanowią pewnego rodzaju specjalizację polskich producentów i swoją jakością oraz ceną przyciągają klientów czeskich. W strukturze podmiotów gospodarczych po polskiej stronie duży udział, zdecydowanie większy niż po czeskiej, stanowily sklepy odzieżowe. $Z$ jednej strony wynika to ze specyfiki handlu $\mathrm{w}$ Polsce, $\mathrm{z}$ drugiej strony popytu lokalnego oraz zgłaszanego przez klientów czeskich. W pozostałych kategoriach struktura placówek usługowych po obu stronach granicy była bardzo podobna. Analizując strukturę podmiotów usługowych, można stwierdzić, że zarówno w Cieszynie, jak i Czeskim 
Cieszynie działają placówki usługowe, będące odpowiedzią na popyt kształtowany przez klientów z drugiej strony granicy. Nastawienie się na klientów z kraju sąsiedniego nie jest tak wyraźne, jak np. po polskiej stronie miast podzielonych na granicy polsko-niemieckiej, które charakteryzują się podażą nakierowaną na klientów zza granicy, korzystających z wyraźnie niższych cen w Polsce, szczególnie usług fryzjerskich, kosmetycznych i dentystycznych oraz artykułów spożywczych. W przypadku miasta podzielonego Cieszyn-Czeski Cieszyn można stwierdzić, że różnice cenowe odgrywają mniej znaczącą rolę w generowaniu turystyki zakupowej, ważne są natomiast takie czynniki, jak jakość, szeroka gama produktów oraz przyzwyczajenia konsumentów.

Biorąc pod uwagę analizowane cechy transgranicznej otwartości firm, wyraźnie widoczne było bardzo duże podobieństwo pomiędzy badanymi miastami (ryc. 1). Podstawowa znajomość języka kraju sąsiedniego była powszechna w obu częściach miasta. Należy podkreślić, że ich mieszkańcy są w stanie na poziomie podstawowym porozumiewać się, używając bądź języka polskiego, bądź czeskiego. Znajomość ta $\mathrm{w}$ istotny sposób wpływa na funkcjonowanie miasta podzielonego, szczególnie w wymiarze praktyki życia codziennego. Sprzyja integracji wspólnot lokalnych, ułatwia korzystanie z różnorakich usług po drugiej stronie granicy i pozytywnie wpływa na kształtowanie powiązań transgranicznych. Obustronna znajomość języka i łatwość porozumiewania się stanowi element wyróżniający Cieszyn oraz Czeski Cieszyn spośród miast podzielonych na polskich granicach, gdzie $\mathrm{z}$ reguły cecha ta ma charakter asymetryczny (np. w miastach polsko-niemieckich Niemcy bardzo rzadko deklarują choćby podstawową znajomość języka polskiego).

Przynajmniej dwukrotnie więcej placówek usługowych odnotowano po czeskiej stronie granicy, gdy pod uwagę wzięto pozostałe cechy otwartości transgranicznej firm. W przypadku jednej z nich, reklamy, generalnie niski był odsetek firm posiadających baner ( $6 \%$ wśród firm polskich, 14\% wśród firm czeskich) oraz materiałów informacyjnych (7\% wśród firm polskich, 16\% wśród firm czeskich) w języku sąsiada. Wydaje się, że niewielka potrzeba reklamowania wynika ze znajomości języka, która ułatwia porozumienie się bezpośrednie. Miasto podzielone Cieszyn-Czeski Cieszyn charakteryzuje się względną symetrycznością pod względem otwartości na klientów z drugiej strony granicy.

Analiza zależności między cechami transgranicznej otwartości ukazała pewne prawidłowości. Po obu stronach miasta widoczna była silna współzależność między badanymi cechami. Jeśli dana placówka usługowa miała jedną z cech, to z reguły posiadała pozostałe cechy, tzn. placówki mające baner w języku sąsiada w $95 \%$ po polskiej stronie, a w $72 \%$ po czeskiej posiadały również materiały informacyjne oraz możliwość płatności w walucie sąsiada (znajomość języka sąsiada ze względu na powszechność nie była analizowana). 


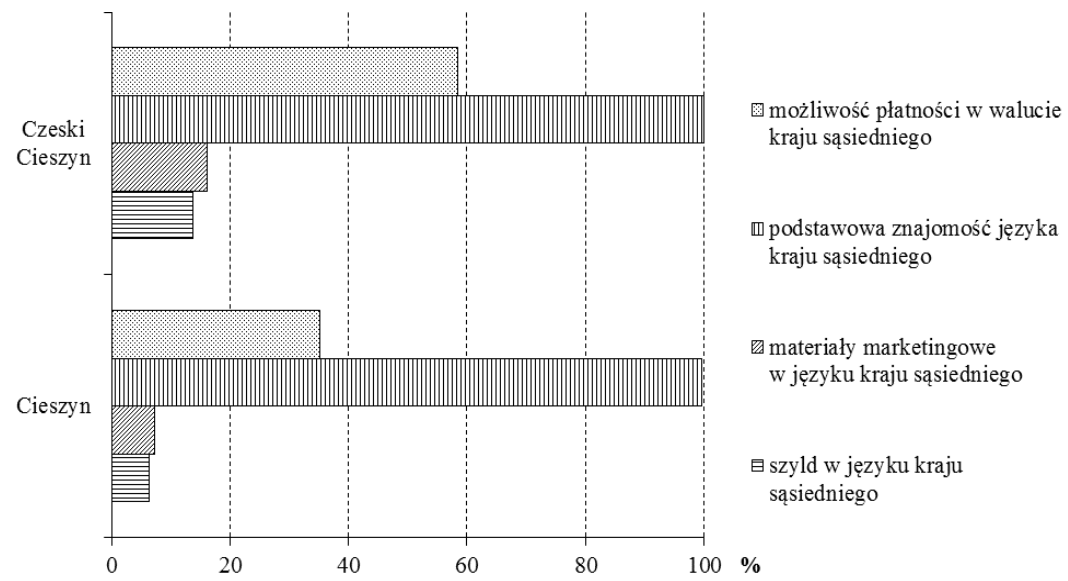

Ryc. 1. Otwartość transgraniczna podmiotów gospodarczych w mieście podzielonym Cieszyn-Czeski Cieszyn w 2011 r. Źródło: opracowanie własne

Rozkład przestrzenny podmiotów gospodarczych według poszczególnych kategorii świadczących o otwartości transgranicznej kształtował się odmiennie w poszczególnych miastach. Wynikał on w sposób bezpośredni z większej liczby i silniejszego rozproszenia firm po stronie polskiej, a ich koncentracji po stronie czeskiej. Biorąc natomiast pod uwagę kwestię otwartości, zaobserwowano podobieństwa obu części w mieście podzielonym Cieszyn-Czeski Cieszyn. Po obu stronach granicy podmioty posiadające baner w języku sąsiada były zlokalizowane głównie w pobliżu przejścia granicznego i przy głównych ulicach prowadzących do centrum. Podobnie kształtował się rozkład przestrzenny firm pod względem posiadania materiałów informacyjnych w języku sąsiada. Jeśli chodzi o możliwość płatności w walucie kraju sąsiedniego, była ona powszechna zarówno w Cieszynie, jak i w Czeskim Cieszynie. Bardzo charakterystyczny był rozkład przestrzenny znajomości języka kraju sąsiedniego, bowiem i po polskiej, i po czeskiej stronie umiejętność ta na poziomie komunikacyjnym była powszechna i odnotowano ją dla prawie wszystkich badanych firm bez względu na odległość od granicy państwowej. Można zatem przyjąć, że w polskiej i czeskiej stronie miasta otwartość transgraniczna była w zasadzie symetryczna.

\section{Podsumowanie}

Otwartość transgraniczna firm usługowych kształtowała się w charakterystyczny sposób w mieście podzielonym Cieszyn-Czeski Cieszyn. Miała ona generalnie charakter symetryczny $\mathrm{z}$ obserwowaną $\mathrm{w}$ obu częściach miasta dużą otwartością na klientów z drugiej strony granicy. Analiza rozkładu przestrzenne- 
go podmiotów gospodarczych z uwzględnieniem cech otwartości transgranicznej pozwala na stwierdzenie, że bliskość miejsca przekraczania granicy miała wpływ na otwartość transgraniczną. Jednostki, które były zlokalizowane w pobliżu mostu granicznego na rzece Olzie, częściej charakteryzowały się otwartością na klientów z drugiej strony granicy niż jednostki od niego oddalone.

Na podstawie przeprowadzonej analizy można stwierdzić, że na względną symetryczność miast z punktu widzenia ich wielkości, liczby mieszkańców, czy też bliskości obu centrów miejskich nakładała się symetryczność charakteru otwartości transgranicznej. Wydaje się, że symetryczność struktur przestrzennych w małym stopniu wpływała na cechy otwartości transgranicznej, bowiem taki układ istniał w przypadku miast podzielonych Zgorzelec-Görlitz (Dołzbłasz, Raczyk 2012) oraz Gubin-Guben, a charakter otwartości był zupełnie odmienny i charakteryzował się dużą asymetrią (wyraźne nastawienie się na klientów niemieckich po polskiej stronie i towarzyszący jej brak otwartości na polskich klientów po niemieckiej stronie). Jakkolwiek duża dostępność i łatwość przemieszczania się mieszkańców między obiema częściami miasta podzielonego miały wpływ na zwiększanie transgranicznej mobilności, to jednak w największym stopniu na poziom otwartości wpływały różnice cen wybranych produktów i usług, jakość i zróżnicowanie oferty, a także uwarunkowania kulturowe.

Pozytywne postrzeganie sąsiadów zza granicy, relatywne częste wizyty mieszkańców po jej drugiej stronie, a także udział w różnorodnych praktykach transgranicznych mają korzystny wpływ na funkcjonowanie obu miast i sprzyjają kształtowaniu relacji współpracy. Można stwierdzić, że bliskość kulturowa (w tym znajomość języka) w znacznie większym stopniu może wpłynąć na procesy integracji przestrzennej i społeczno-ekonomicznej w miastach podzielonych niż zróżnicowanie cen produktów i usług. Generują one bowiem mobilność transgraniczną, ale raczej nie przekładają się na zbliżanie mieszkańców miast podzielonych do siebie czy też integrację przestrzenną. Ich istnienie należy jednak ocenić pozytywnie, gdyż w sposób bezpośredni wpływają na możliwość wytwarzania większych dochodów z handlu i usług, a w sposób pośredni mają także wpływ na oswajanie się mieszkańców z przestrzenią miasta sąsiedniego. Może się to przyczynić do procesu integracji przestrzennej w przyszłości. Wydaje się natomiast, że w przypadku sąsiadowania społeczności bliższych sobie ze względu na uwarunkowania kulturowe i społeczno-gospodarcze (ze względu na m.in. występowanie mniejszości narodowych i przez to mieszanych rodzin, wzajemną znajomość języka), szanse te są większe. Należy podkreślić przy tym, że w kontekście możliwości kształtowania wspólnych procesów rozwoju dla całego miasta podzielonego z pewnością korzystniejszy jest układ symetryczny pod różnym względem, w tym także otwartości transgranicznej placówek usługowych. 


\section{Literatura}

Ackleson J., 2005, Constructing security on the U.S.-Mexico border, „Political Geography", 24, s. 165-184.

Agnew J., 2008, Borders on the mind: reframing border thinking, „Ethics and Global Politics", 1 (4), s. 175-191.

Arreola D., 1996, Border-city idee fix, „Geographical Review”, 86 (3), s. 356-369.

Brunet-Jailly E., 2011, Special section: borders, borderlands and theory: an introduction, „Geopolitics”, 16, s. 1-6.

Buttin F., 2006, The Polish-Czechoslovak conflict over Teschen Silesia (1918-1920): a case study, „Perspectives”, 25, s. 63-78.

Bygvrå S., Westlund H., 2004, Shopping behaviour in the Øresund Region before and after the establishment of the fixed link between Denmark and Sweden, „GeoJournal”, 61, s. 41-52.

Dołzbłasz S., 2013, Cross-border co-operation in the euroregions at the Polish-Czech and Polish-Slovak borders, „European Countryside”, 5 (2), s. 102-114.

Dołzbłasz S., Raczyk A., 2012, Transborder openness of companies in a divided city. Zgorzelec/Görlitz case study, „Tijdschrift voor economische en sociale geografie”, 103 (3), s. 347-361.

First Espon Synthesis Report, 2013, New Evidence on Smart, Sustainable and Inclusive Territories, European Union.

Gerber J., Lara F., de la Parra C., 2010, Re-imagining the U.S.-Mexico border: Policies towards a more competitive and sustainable transborder region, „Global Economy Journal", 10 (4), s. 1-17.

Houtum H. van, 1999, Internationalisation and mental borders, „Tijdschrift voor Economische en Sociale Geografie", 90, s. 329-335.

Jańczak J., 2009, Conflict and cooperation in divided cities, Thematicon, 14, Berlin.

Jańczak J., 2013, Border twin towns in Europe. Cross-border cooperation at a local level, Berlin.

Knippschild R., 2011, Cross-border spatial planning: understanding, designing and managing cooperation processes in the German-Polish-Czech borderland, „European Planning Studies", 19 (4), s. 629-645.

Krätke S., Borst R., 2007, EU Eastern enlargement and the configuration of German-Polish inter-firm linkages, „Tijdschrift voor Economische en Sociale Geografie”, 98, s. 621-640.

Kulczyńska K., 2010, The Gubin-Guben transborder urban complex as an arena of consumer behaviour, „Bulletin of Geography Socio-economic Series”, 14, s. 79-89.

Kulczyńska K., Matykowski R., 2008, Struktura przestrzenno-handlowa przygranicznego zespołu miejskiego Česky Těšin-Cieszyn, „Dokumentacja Geograficzna”, 36, s. 202-207.

Kulczyńska K., Matykowski R., 2011, Images of the urban spaces of Cieszyn, „Bulletin of Geography Socio-economic Series", 15, s. 83-94. 
Kurkowiak B., 2013, Comparative price levels for food, beverages and tobacco, Statistics in focus. Economy and Finance, no 15, Eurostat.

Leimgruber W., 2005, Boundaries and transborder relations, or the hole in the prison wall: On the necessity of superfluous limits and boundaries, „GeoJournal”, 64, s. 239-248.

Lundén T., 2004, On the boundary. About humans at the end of territory, Huddinge.

Newman D., 2006, The lines that continue to separate us: borders in our borderless' World, „Progress in Human Geography”, 30 (2), s. 143-161.

Newman D., 2010, Territory, compartments and borders: Avoiding the trap of the territorial trap, „Geopolitics”, 15 (4), s. 773-778.

O'Dowd L., 2010, From a 'borderless world' to a 'world of borders': bringing history back in, „Environment and Planning D: Society and Space”, 28 (6), s. 1031-1050.

Paasi A., 2011, Border theory: an unattainable dream or a realistic aim for border scholars?, [w:] Wastl-Walter D. (red.), A research companion to border studies, Aldershot, s. 11-31.

Pokluda F., 2005, Orlicko: a rural microregion on the Czech-Polish state border, „Europa XXI”, 13, s. 173-184.

Reitel B., 2006, Governance in cross-border agglomerations in Europe - the examples of Basel and Strasbourg, „Europa Regional”, 14 (1), s. 9-21.

Reitel B., 2013, Border temporality and space integration in the European transborder agglomeration of Basel, ,Journal of Borderlands Studies”, 28 (2), s. 239-256.

Rippl S. i in., 2010, Crossing the frontier: transnational social integration in the EU'S border regions, ,International Journal of Comparative Sociology”, 51 (1-2), s. 5-31.

Siwek T., 2008, Nazwiska jako indykator pochodzenia ludności miasta Český Těšín, „Dokumentacja Geograficzna”, 36, s. 196-201.

Sohn C., 2013, The border as a resource in the global urban space: a contribution to the cross-border metropolis hypothesis, „International Journal of Urban and Regional Research", DOI:10.1111/1468-2427.12071.

Sohn C., Lara-Valencia F., 2013, Borders and cities: perspectives from North America and Europe, „Journal of Borderlands Studies”, 28 (2), s. 181-190.

Spierings B., van der Velde M., 2008, Shopping, borders and unfamiliarity: consumer mobility in Europe, ,Tijdschrift voor Economische en Sociale Geografie”, 99, s. 497505.

Topaloglou L. i in., 2005, A border regions typology in the enlarged European Union, „Journal of Borderlands Studies”, 20 (2), s. 67-89.

Vaishar A. i in., 2013, Contemporary development of peripheral parts of the Czech-Polish borderland: case study of the Javornik area, „Geographia Polonica”, 86 (3), s. 237-253.

Velde M. van der, Sperings B., 2010, Consumer mobility and the communication of difference: reflecting on cross-border shopping practices and experience in the Dutch-German borderland, „Journal of Borderlands Studies”, 25, s. 191-205.

Więckowski M., 2013, Eco-frontier in the mountainous borderlands of Central Europe. The case of Polish border parks, „Journal of Alpine Research”, 101 (2), DOI: 10.4000/rga.2107. 
Zenderowski R., 2002a, Stosunki między mieszkańcami miast podzielonych granica państwowa na przykladzie Cieszyna i Czeskiego Cieszyna (Český Těšín), „Studia Regionalne i Lokalne", 1 (8), s. 49-78.

Zenderowski R., 2002b, Cieszyn jako miasto podzielone granica państwowa. Przyczyny $i$ konsekwencje podzialu z 1920 r., „Sacculum Christianum”, 9 (1), s. 107-126.

\title{
Cieszyn-Český Těšín - selected aspects of a divided city at the Polish-Czech border functioning in the context of transborder mobility
}

\begin{abstract}
Summary
The existence of national borders does not only mean formal-legal barriers, but also, or above all, mental and economical barriers and as a consequence the pace and scope of integration processes depend on local conditions e.g. local actors, physical barriers, infrastructural connections, differences in the level of economic development. In the context of transborder mobility divided cities appear to be a good research subject in terms of immediate neighbourhood, population density and concentration of institutions, etc. resulting in high intensity of social, economic and spatial phenomena and processes on both sides of the border and the opportunity to research the impact of the border on these processes. The existence of a border in everyday life of the inhabitants and ample potential opportunities for integration are also very important factors.

The aim of this study was to research selected aspects of transborder practices at the local level in Cieszyn-Český Těšín, the divided city at the Polish-Czech border. In the paper the transborder openness of service providers and transborder mobility of inhabitants were chosen for analysis. The study on firms covered the urban centres on both sides of the border and the space connecting them to the border crossings. Economic entities providing chosen services for the people, such as: retailers, gastronomy, museums and selected offices were researched. The study aimed to show the level of openness of these institutions to clients from the other side of the border (e.g. offers in the language of the neighbour, possibilities of payment in the neighbour's currency, knowledge of the language). This allows, in turn, to determine the level of permeability of institutional space, its character, strength etc. The intensity of transborder mobility and attitude towards neighbours were assessed on the basis of a questionnaire survey conducted among the inhabitants of Cieszyn.

The permeability of institutional space and perception of neighbours seems to be a significant elements of the integration processes of the divided city. It was assumed that the high level of transborder openness as well as intensive and positive relations between local communities may lead to the formation of a common public space and strong functional connections. The analysis has shown positive attitude towards inhabitants of the other side of the border. Moreover, relatively intensive connections between citizens of Cieszyn and Český Těšín was observed. As regards transborder openness of service providers a clear symmetry was visible (common knowledge of neighbour's language, moderate share of firms with banner/marketing materials in neighbours'
\end{abstract}


language). In the scope of the type structure of analysed firms, however, some differences were noticed (e.g. higher share of restaurants and bars on the Czech side, higher share of clothes shops on the Polish side). It can be stated that except for the economic factor, cultural factors are also significant elements shaping the permeability of institutional space and perception of the neighbours across the border in the divided city.

Keywords: divided city, border twin city, transborder shopping trips, cross-border relations, Polish-Czech border.

Sylwia Dołzbłasz, dr

Zakład Zagospodarowania Przestrzennego, Instytut Geografii i Rozwoju Regionalnego, Uniwersytet Wrocławski, 50-138 Wrocław, ul. Kuźnicza 49-55 